Stilistika: Jurnal Bahasa, Sastra, dan Pengajarannya

ISSN 2527-4104

Vol. 1 No.1, 1 April 2016

\title{
PENDIDIKAN AGAMA ISLAM DALAM NOVEL TUHAN, AKU KEMBALI KARYA HAIDAR MUSYAFA
}

\author{
Eka Adi Saputra dan Heppy Lismayanti \\ Program Studi Pendidikan Bahasa dan Sastra Indonesia \\ STKIP PGRI Banjarmasin, \\ Email: heppylismayanti2@gmail.com
}

\begin{abstract}
Abstrak
Pendidikan Agama Islam dalam Novel Tuhan, Aku Kembali Karya Haidar Musyafa. Penelitian ini mengkaji tentang akhlak dan kepribadian sesuai dengan pendidikan agama Islam. Masalah yang akan diteliti adalah (1) pendidikan agama Islam dari segi akhlak, dan (2) pendidikan agama Islam dari segi kepribadian. Tujuan penelitian ini untuk (1) mendeskripsikan pendidikan agama Islam dari segi akhlak, dan (2) mendeskripsikan pendidikan agama Islam dari segi kepribadian dalam novel Tuhan, Aku Kembali karya Haidar Musyafa. Pendekatan yang digunakan adalah pendekatan sosiologis. Jenis penelitian yang digunakan yaitu jenis penelitian kualitatif. Sumber data yang digunakan dalam novel ini adalah novel yang berjudul Tuhan, Aku Kembali karya Haidar Musyafa. Novel ini diterbitkan oleh PT. Buku Kita dengan tebal buku 208 halaman. Teknik pengumpulan data yang digunakan dalam penelitian ini adalah studi teknik dokumentasi. Teknik analisis data menggunakan metode deskriptif analisis.Simpulan penelitian ini adalah (1) Pendidikan agama Islam dari segi akhlak dalam novel memiliki beberapa bagian penting di dalamnya seperti jujur, sabar, sikap baik, dan ikhlas. (2) Pendidikan agama Islam dari segi kepribadian dalam novel memiliki beberapa bagian penting di dalamya seperti keseluruhan sikap, perasaan, temperamen, dan perilaku.
\end{abstract}

Kata-kata kunci: pendidikan agama Islam, perspektif sosiologi sastra, novel

\section{PENDAHULUAN}

Karya sastra merupakan hasil karya cipta manusia yang terlahir dari unsur pemikiran yang terdapat dalam suatu karya tersebut mengandung nilai-nilai moral, religi, sosial maupun budaya. Karya sastra merupakan media bagi pengarang sebagai wadah untuk menuangkan pengalaman jiwa yang bersifat karya seni. Sebuah karya sastra menceritakan berbagai masalah kehidupan manusia di masyarakat dan lingkungan, hubungan sesama manusia dan dengan Tuhannya. Meskipun berupa khayalan, karya sastra tetap tidak bisa dianggap sebagai karya seni yang semu, karena dalam suatu karya sastra, khayalan, lamunan dan renungan dilakukan dengan penuh kesadaran. Menurut Semi, (1993:8) "Sastra itu adalah suatu bentuk dan hasil pekerjaan seni kreatif yang objeknya adalah manusia dan kehidupannya dengan menggunakan bahasa sebagai mediumnya. Sastra harus mampu menghasilkan suatu 
kreasi yang indah sehingga dapat menjadi penyalur ide keindahan pemikiran manusia".

Novel merupakan salah satu bentuk dari sebuah karya sastra dan merupakan sebuah karya fiksi yang menjelaskan tentang berbagai macam permasalahan dalam hidup manusia. Sebuah novel biasanya menceritakan tentang kehidupan manusia, lingkungannya dan dengan Tuhannya.

Novel Tuhan, Aku Kembali merupakan salah satu karya yang ditulis oleh Haidar Musyafa. Novel ini menceritakan tentang hidup seorang Ustadz, beliau adalah Ustadz Jeffrey Al Buchori dari masa kecil hingga beliau menjadi seorang ustadz yang tentu menjadi panutan, beliau lahir dan dibesarkan di lingkungan keluarga yang taat dalam menjalankan ajaran agama Islam, yang secara otomatis membuat beliau mengerti mana yang baik dan buruk menurut agama, namun lingkungan keluarga yang baik saja tidaklah cukup, pengaruh terbesar dalam membentuk suatu perilaku adalah di lingkungan masyarakat, masa kecil yang tadinya dipengaruhi oleh bekal ajaran agama yang kuat menjadi hancur karena pergaulan. Kisah lengkap perjalanan hidup beliau dapat kita temukan dinovel karya Haidar Musyafa ini. Penulis merupakan putra pertama pasangan Bapak Sudarman dan Ibu Wantinem, lahir di Sleman, 29 Juni 1986 dalam keluarga yang sederhana membuatnya gigih dalam memperjuangkan harapan dan cita-citanya. Semua jenjang pendidikannya dari Sekolah Dasar hingga Perguruan Tinggi diselesaikan di Yogyakarta.

Haidar Musyafa juga memiliki usaha jasa media yaitu CV. Media Insan Sejahtera. Pria pecinta nasyid ini juga mengikuti beberapa organisasi penting yang bisa menjadi sarana untuk saling berbagi pengalaman dan meningkatkan pengetahuannya di dunia bisnis. Organisasi yang diikutinya adalah JPMI (Jaringan Pengusaha Muda Indonesia), MES (Masyarakat Ekonomi Syari'ah), dan KPMI (Komunitas Pengusaha Muslim Indonesia). Untuk meningkatkan pengetahuannya tentang dunia tulis-menulis pria yang hobi jalan-jalan ini juga aktif mengikuti beberapa komunitas penulis, diantaranya Pesantren Penulis, Re! Media Servis, Komunitas Sastra Indonesia, Serambi Ilmu, Pecinta Fiksi dan beberapa organisasi lainnya.

Penelitian pernah dilakukan oleh peneliti terdahulu, diantaranya, Jailani (STKIP PGRI Banjarmasin tahun 2015) dengan judul "Nilai-Nilai Pendidikan Dalam Novel Sang Pemimpi Karya Andrea Hirata (Analisis Sosiologi Sastra). Penelitian yang dilakukan Jailani tersebut mengkaji tentang nilai pendidikan namun dengan analisis sosiologi sastra, meskipun dari segi judul cukup memiliki kesamaan dengan penelitian yang dilakukan peneliti saat ini, tetapi terdapat perbedaan pada kajian penelitian.

Perbedaan antara penelitian terdahulu dan penelitian ini adalah dari segi judul, objek penelitian, dan fokus penelitian yang terdapat pada rumusan masalah dalam novel Tuhan, Aku Kembali karya Haidar Musyafa meceritakan tentang kehidupan sosial. Penelitian ini mengungkapkan bagaimana pergaulan hidup di masyarakat dan menjadikan pendidikan khususnya pendidikan agama Islam sebagai acuan.

Berdasarkan uraian tersebut, peneliti tertarik untuk meneliti lebih lanjut mengenai apa saja yang terdapat dalam pendidikan agama Islam di kehidupan seharihari mengenai akhlak dan kepribadian. Melalui alasan dan keingintahuan yang kuat 
terhadap suatu novel yang menjadi pilihan peneliti ialah novel Tuhan, Aku Kembali karya Haidar Musyafa.

\section{METODE}

Guna mendapatkan gambaran mengenai pendekatan dan jenis penelitian yang digunakan, maka berikut ini disajikan mengenai landasan teori pendukung tentang pendekatan dan jenis penelitian yang meliputi: 1) pendekatan penelitian, dan 2) jenis penelitian. Pendekatan yang digunakan peneliti dalam menganalisis pendidikan agama Islam di dalam kehidupan tentang dalam novel Tuhan, Aku Kembali karya Haidar Musyafa, yaitu dengan menggunakan pendekatan sosiologis. "Pendekatan sosiologi yaitu pendekatan yang menganalisis manusia dalam masyarakat, dengan proses pemahaman mulai dari masyarakat ke individu" (Ratna, 2011:59). Ciri yang menjadi penanda dalam metode penelitian jenis kualitatif adalah: 1) memberikan perhatian utama pada makna pesan, 2) proses lebih diutamakan dibandingkan hasil penelitian sehingga maknanya selalu berubah, 3) tidak ada jarak antara subjek penelitian sebagai instrument dan objek penelitian, 4) kerangka penelitian bersifat sementara, sebab penelitian bersifat terbuka, dan 5) penelitian bersifat alamiah, terjadi sesuai konteksnya (Ratna, 2012:47-48). Penerapan dari jenis penelitian kualitatif adalah mengkaji hubungan perilaku agama Islam dengan akhlak dan kepribadian yang terdapat dalam novel Tuhan, Aku Kembali karya Haidar Musyafa terkait dengan pendidikan agama Islam di kehidupan sehari-hari baik di lingkungan keluarga maupun lingkungan masyarakat.

\section{HASIL DAN PEMBAHASAN}

\section{Sinopsis Novel Tuhan, Aku Kembali Karya Haidar Musyafa}

Novel ini adalah kisah perjalanan hidup dari seorang Ustadz yang menjadi panutan khususnya dikalangan anak muda, dia adalah Ustadz Jeffrey Al Buchori banyak hal yang tidak diketahui masyarakat tentang Uje panggilan akrab beliau, sebelum Uje menjadi ustadz yang sangat dikagumi banyak orang. Ada banyak cerita, masalah, hal yang berat yang harus Uje jalani. Alhamdulillaah, pada akhirnya, Uje memang menjadi sosok ustadz yang dekat dengan rakyat kecil. Dia tidak mengekslusifkan diri meski namanya sudah terkenal dan seorang ustadz yang ahli agama. Haidar Musyafa sebagai penulis novel ini mencoba membawa pembaca agar lebih mengenal sosok Uje lebih dekat, dari lahir sampai Tuhan memanggilnya kembali.

Jakarta, 12 April 1973 lahirlah seorang anak laki-laki bernama Jeffrey Al Buchori Modal. Ayah beliau bernama Mohammad Ismail Modal dan Ibu beliau Tatu Mulyana, Jefri terlahir di lingkungan keluarga yang taat agama sehingga setelah lulus Sekolah Dasar orangtua beliau memasukkan beliau kepondok pesantren tepatnya di Pondok Pesantren Dar el-Qalam di daerah Tangerang. Pesantren tersebut merupakan pondok pesantren terbaik yang telah melahirkan banyak sekali Kyai dan guru ngaji, bersama kedua kakak beliau yaitu Abdullah Riyad dan Aswan Faisal beliau menimba ilmu di pesantren. 
Perubahan perilaku Jefri mulai terlihat ketika dia menimba ilmu di pesantren, Jefri yang tadinya adalah anak yang baik dan pintar menjadi nakal dan sulit diatur. Jefri yang dulunya rajin beribadah, patuh dan taat terhadap nasehat orangtua, berubah menjadi anak yang sulit diatur. Namun Jefri adalah termasuk anak yang pandai dan cerdas, terbukti beliau pernah menjadi juara pertama lomba Musabaqah Tilawatil Qur'an (MTQ), juara pertama lomba Qasidah dan Shalawatan, itu adalah prestasi yang pernah dibuat Jefri saat berada di pesantren yang membuat Apih dan Umi beliau meneteskan air mata. Tetapi hal ini tidak sertamerta membuat Jefri menjadi anak yang baik, beliau tetap saja menunjukkan sikap yang kurang baik, sering bolos saat jam pelajaran, merokok, meninggalkan shalat dan perbuatan nakal lainnya yang akhirnya membuat kedua orangtua dia sangat kecewa dan merasa gagal dalam mendidik Jefri kecil.

Apih dan Umi yang sudah sangat kecewa dengan sikap serta perilaku Jefri, dan memutuskan untuk memindahkan jefri dari pesantren dan menyekolahkan Jefri di Madrasah Aliyah. Tetapi hal tersebut tambah membuat Jefri semakin tidak terkontrol, dia semakin nakal dan sulit diatur karena kenakalan Jefri tersebut dia hanya bertahan di Aliyah selama satu tahun. Namun Apih dan Umi tidak menyerah dan kembali memasukkan Jefri ke SMA, dan benar saja kelakuan buruk Jefri mulai berkurang yang tentu saja membuat Apih dan Umi merasa senang tetapi itu tidak langsung membuat Jefri menjadi berkelakuan baik seperti semula.

Setelah lulus SMA, bukan bertambah dewasa tetapi sifat buruk Jefri makin menjadi, dia mulai mengenal dunia malam pergi kediskotik, mengenal obat-obat terlarang dan menjadi pemakai narkoba. Seiring bertambahnya usia, Jefri pun mulai mengurangi kebiasaan buruknya dan mulai memikirkan tentang masa depan, keinginan untuk terus mengembangkan karir di dunia hiburan memunculkan keinginan untuk melanjutkan pendidikan keperguruan tinggi di jurusan broadcasting. Karir Jefri berkembang dengan pesat setelah mengenal Aditya Gumai dari dia lah Jefri mengenal dan jatuh cinta pada dunia akting. Kehidupan Jefri semakin bebas dan tak terarah sehingga membuat orangtua beliau semakin kecewa karenanya. Sampai pada akhirnya orangtua Jefri meninggal dunia beliau tentu tidak pernah mengharapkan anaknya menjadi seperti ini, Jefri yang diharapkan menjadi anak yang baik, memiliki akhlak dan kepribadian baik akhirnya menjadi hancur karena pergaulan. Namun hidup Jefri mulai menjadi terarah ketika dia mengenal Pipik Dian Irawati wanita cantik yang bekerja di perusahaan Jepang dan menjadikan model sebagai pekerjaan sampingan. Jefri merupakan bintang sinetron yang cukup terkenal waktu itu dan Pipik juga merupakan salah satu penggemar berat Jefri. Perjalanan cinta Jefri dan Pipik dimulai, mereka berdua saling menaruh hati meski pada awalnya ditentang oleh sahabat Pipik yaitu Gugun Gondrong, Gugun mengetahui bagaimana kelakuan Jefri termasuk kebiasaan Jefri mengkonsumsi narkoba sehingga Gugun tidak setuju jika Pipik berhubungan dengan Jefri. Tetapi Jefri terus berusaha mendekati Pipik dan pada akhirnya memperkenalkan Pipik kepada Umi dan kakakkakak Jefri yang kebetulan berkumpul di rumah.

Jefri akhirnya menikahi Pipik lewat resepsi pernikahan yang sederhana dan Pipik pun resmi menjadi istri Jefri. Kehidupan sesungguhnya baru dimulai, kedewasaan Jefri diuji dari bagaimana cara dia memimpin rumah tangganya. Jefri 
yang belum memiliki pekerjaan dan masih terjerat narkoba menjadikan dia laki-laki yang tidak bertanggungjaawab, namun Pipik tak henti untuk selalu menyadarkan dan menguatkan Jefri sehingga perlahan dia kembali kejalan yang di ridhoi Allah swt. Hingga pada saat keluarga Jefri sedang berkumpul bersama, kakak pertama beliau yaitu Abdullah Riyad menawarkan Jefri untuk menjadi khotib shalat jumat di masjid, Jefri merasa tersanjung namun merasa tidak percaya diri bahwa dia akan mampu, tetapi dorongan yang tak henti dari keluarga dan sang istri membuat dia menyanggupi tawaran tersebut. Jefri berlatih dengan keras, semua kemampuan dia kerahkan untuk menjadi khotib dan benar saja, pada hari jumat Jefri menjadi khotib, khotbah yang disampaikan beliau membuat hati semua jamaah masjid shalat jumat itu menjadi tersentuh, semua menyukai dan menyanjung Jefri yang akhirnya memanggil dan menjadikan Jefri sebagai Ustadz Jeffrey Al Buchori atau yang biasa disapa Uje. Menjadi Ustadz tentu membuat perekonomian Jefri menjadi meningkat, beliau mampu menafkahi istri dan keempat anak beliau melalui jalan dakwah sambil mendapat pahala dari dakwah yang dijalankannya. Hal tersebut tidak membuat beliau merasa sombong, Uje tetaplah seorang yang rendah hati, peduli dengan keadaan sekitar, dengan segala yang telah dimilikinya Uje merasa ada yang kurang dalam dirinya, dia masih merasa menjadi seorang manusia yang penuh dosa dan belum pantas menyandang gelar Ustadz.

April 2013, tiga orang pemuda sedang asik berbincang di sebuah kafe black canyon di daerah Jakarta. Tiga pemuda itu ialah Ustadz Ecep Jumhur, Ustadz Agus Idwar dan Ustadz Jeffry Al Buchori, mereka asik membicarakan tentang kegiatan bulan Ramadhan, keasikkan membicaran hal tersebut membuat mereka lupa waktu sudah larut malam bahkan mendekati subuh. Uje memutuskan untuk pulang lebih dulu dan berpamitan dengan kedua sahabat beliau tersebut, langkah dengan langkah gontai Uje menuju kearah parkir untuk mengambil motor kesayangan beliau yaitu Kawasaki ER 650cc, motor hijau yang menjadi kesayangan beliau. Uje mengendarai motor tersebut pulang menuju rumah, udara dingin dan hujan yang turun tidak membuat beliau menghentikan laju motornya, beliau malah semakin mempercepat laju motornya,

Jumat, 26 April 2013 di jalan gedung hijau raya pondok indah, motor yang dikendarai Ustdz Jeffry Al Buchori mengalami kecelakaan, motor yang dikendarai beliau menabrak pembatas jalan dan menghantam pohon, tubuh Uje terpenlanting dan terkapar dijalan. Kedua sahabat Uje ternyata menyaksikan kejadian tersebut dari jarak 50 meter, mereka yang melihat hal tersebut panik dan langsung melarikan Uje ke Rumah sakit pondok indah, tetapi kerena keadaan beliau yang semakin kritis, maka dokter menyarankan agar beliau di rujuk ke Rumah Sakit Fatmawati. Dalam proses evakuasi itulah Allah swt memanggil Uje. Uje meninggal pada usia 40 tahun. Selamat jalan, Uje. Semoga Allah swt meridhaimu di dunia dan di akhirat.

\section{Pendidikan Agama Islam dari Segi Akhlak Terkait dengan Kejujuran}

Jujur merupakan tindakan sangat terpuji yang diwariskan sejak zaman para nabi hingga saat ini. Seseorang hendaklah memiliki sikap jujur sebagai cerminan akhlak yang baik. Kejujuran dimasa sekarang ini menjadi hal yang luar biasa untuk 
dilakukan. Seperti yang terdapat dalam novel Tuhan, Aku Kembali. Perhatikan kutipan di bawah ini!

"Awal-awal di pesantren, aku merasa tidak betah tinggal di sana. Semuanya serba rumit diatur. Di sana aku harus bangun lebih pagi, masak sendiri, mencuci sendiri, dan setelah itu baru belajar di sekolah yang terkadang harus berlanjut sampai malam hari."

\section{Pendidikan Agama Islam dari Segi Akhlak Terkait dengan Sabar}

Perilaku terpuji yang hanya dimiliki orang-orang yang menjalankan ibadah sesuai syariat Islam dan menerapkannya di kehidupan sehari-hari. Sabar menjadi aspek cerminan akhlak baik. Sabar adalah menahan diri dari emosi yang tak terkendali. Berikut kutipannya.

"Air mataku semakin deras mengalir saat Apih memeluk tubuhku dan berkata seperti ini. Padahal, aku sering membuatnya marah dan kecewa. Tapi ternyata perhatian dan kasih sayangnya tidak pernah padam. Apih dan Umi masih tetap memperhatikanku dengan penuh cinta dan kasih sayangnya yang tulus."

\section{Pendidikan Agama Islam dari Segi Akhlak Terkait dengan Sikap Baik}

Sikap baik merupakan perilaku yang dimiliki manusia, menjadi sikap yang terlihat menonjol dalam pergaulan. Sikap baik tidak bisa dibuat-buat, sikap baik akan terlihat dari pengetahuan agama dan bagaimana seseorang menerapkan pengetahuan tersebut dalam hidup. Berikut kutipannya.

"Sepulangnya dari menunaikan ibadah umrah di tanah suci aku mencoba untuk hidup di jalan yang benar. Aku berusaha dengan sekuat tenaga agar kemaksiatan dan narkoba tidak lagi merampas hidupku kembali. Hari-hari aku gunakan untuk coba merenungi diri, tentang semua dosa dan kesalahan yang selama ini telah aku kerjakan."

\section{Pendidikan Agama Islam dari Segi Akhlak Terkait dengan Ikhlas}

Suatu perbuatan memberi maupun menerima, namun tak pernah mengharapakan suatu balasan. Ikhlas adalah sebuah ketulusan yang menjadi gambaran akhlak manusia yang memahami dan menerapkan pendidikan agama dalam kehidupan. Berikut kutipannya.

"Kesabaran, kesederhanaan, ketekunan, dan kelembutan yang dimilikinya tidak pernah berubah walaupun Apih sudah tidak berada di sisinya lagi. Umi berusaha menjalani kehidupannya sebagai janda dengan ikhlas dan tegar. Walaupun ditinggal Apih pergi menghadap Allah namun Umi tidak pernah terlihat bersedih hati. Umi masih bisa tersenyum bahagia karena masih memiliki anak-anak yang dapat meramaikan suasana hatinya yang sepi." 


\section{Pendidikan Agama Islam dari Segi Kepribadian Terkait dengan Keseluruhan Sikap}

Perilaku yang ditunjukkan manusia dalam kehidupannya, baik maupun buruk perilaku manusia tersebut akan terlihat dikarenakan keseluruhan sikap adalah gambaran seutuhnya dari kepribadian manusia. Pergaulan juga dapat memberi pengaruh dalam keseluruan sikap pada manusia. Seperti kutipan berikut.

"Memang, selama di pesantren aku bergaul dengan orang-orang yang bisa dibilang agak bandel jika dibandingkan dengan temantemanku sewaktu aku masih duduk di Sekolah Dasar. Mungkin saja pergaulanku dengan merekalah yang menjadi salah satu sebab perubahan watak dan perilakuku sehari-hari. Di pesantren, tak jarang aku berbuat jahil pada teman-temanku yang berjenis kelamin perempuan. Aku sering mengganggu dan menakut-nakuti mereka dengan mainan binatang berbisa yang terbuat dari karet berbentuk ular, kalajengking, lipan, dan sebagainya. Pada saat mereka lari ketakutan dan menanggis, aku merasa sangat puas karena telah berhasil menjahili mereka."

\section{Pendidikan Agama Islam dari Segi Kepribadian Terkait dengan Perasaan}

Perasaan merupakan suatu gambaran ekspresi jiwa yang mencerminkan keadaan hati manusia. Seseorang yang mampu mengendalikan perasaannya akan menimbulkan suatu kepribadian yang baik. Berikut kutipannya.

"Aku merasakan ada kerinduan yang membuncah di dadaku ketika Umi lama sekali tak mengunjungiku di pesantren. Aku tidak tau persis alasan Apih dan Umi mengapa sudah lama sekali tidak berkunjung ke pesantren. Padahal biasanya Apih dan Umi mengunjungiku satu minggu sekali. Kejadian itu membuat hatiku dipenuhi dengan berbagai macam prasangka. Jangan-jangan Apih dan Umi sudah benar-benar marah padaku? Hatiku semakin tidak karukaruan. Sedih juga rasanya tidak dikunjungi orangtua beberapa saat lamanya."

\section{Pendidikan Agama Islam dari Segi Kepribadian Terkait dengan Temperamen}

Suatu bentuk emosional manusia ketika dihadapkan pada suatu keadaan yang membuat dirinya merasa terdesak dan tidak nyaman. Marah merupakan suatu hal yang masuk ke dalam aspek temperamen, marah bisa disebabkan hal baik, tetapi juga bisa disebabkan hal yang buruk. Berikut kutipannya.

"Melihat Apih dan Umi marah-marah, aku lantas diam saja. Aku selalu membantah semua nasehat-nasehatnya. Itulah yang kemungkinan membuat Apih semakin jengkel." 
Keadaan tak sadarkan diri mampu membuat temperamen seseorang naik hingga tak terkendalai. Minuman keras adalah hal yang mampu membuat manusia tidak dapat mengontrol emosinya.

\section{Pendidikan Agama Islam dari Segi Kepribadian Terkait dengan Perilaku}

Suatu tindakan atau perbuatan yang dilakukan manusia dalam menjalani hidup, baik itu di lingkungan keluarga maupun masyarakat. Tindakan tersebut mencerminkan perilaku yang menunjukkan bagaimana kepribadian manusia tersebut. Seperti pada kutipan berikut.

"Kenakalan-kenakalan itulah yang membuat aku sering di sidang di hadapan majelis pesantren. Sudah tak terhitung lagi berapa kali aku diberi peringatan dan hukuman, dengan tujuan agar aku insyaf dan jera. Sayangnya, aku tidak pernah merasa jera. Bahkan semakin hari kenakalanku terus saja meningkat dan semakin menjadi-jadi."

Perilaku baik maupun buruk akan sangat dipengaruhi oleh lingkungan dan pergaulan. Seperti kutipan berikut.

"Di sekolah yang baru ini kenakalanku agak sedikit mereda. Apih dan Umi bisa sedikit tersenyum lega. Pasalnya aku sudah disibukkan dengan kegiatan-kegiatan keagamaan sejak di awal-awal aku masuk sekolah tersebut. Tapi, kenakalan dan kebandelanku kemudian datang lagi. Setelah beberapa bulan berada di sekolah yang baru ini, rupanya aku menemukan komunitas teman-teman baru yang juga memberiku petualangan baru. Hal-hal baru tersebut semuanya belum pernah aku dapat sewaktu di pesantren maupun Aliyah. Biasanya aku dan teman-temanku sering membolos dan bersembunyi di dalam kantin. Bahkan, untuk mengikuti pelajaran pun aku melakukannya dengan malas-malasan."

\section{PENUTUP}

\section{Kesimpulan}

Berdasarkan hasil dan pembahasan di atas terhadap novel Tuhan, Aku Kembali karya Haidar Musyafa, maka dikemukakan beberapa kesimpulan, yaitu Pendidikan agama Islam dari segi akhlak dalam novel memiliki beberapa bagian penting di dalamnya seperti jujur, sabar, sikap baik, ikhlas dan Pendidikan agama Islam dari segi kepribadian dalam memiliki beberapa bagian penting di dalamya seperti keseluruhan sikap, perasaan, temperamen, perilaku.

\section{Saran}

Terkait dengan hasil penelitian yang dilakukan peneliti diharapkan agar penikmat karya sastra mengapresiasikan novel Tuhan, Aku Kembali karya Haidar Musyafa sebagai suatu pelajaran serta gambaran, karena dalam novel ini banyak nilai-nilai pendidikan di dalamnya serta dapat membangkitkan semangat seseorang. 
Vol. 1 No.1, 1 April 2016

\section{DAFTAR RUJUKAN}

Jailani, Akbar. 2015. Nilai-nilai Pendidikan Dalam Novel Sang Pemimpi Karya Andrea Hirata. Skripsi tidak terbit. Banjarmasin: STKIP PGRI Banjarmasin.

Musyafa, Haidar. 2014. Tuhan, Aku Kembali. Yogyakarta: Citra Media Pustaka.

Ratna, Kutha Nyoman. 2011. Teori, Metode, dan Teknik Penelitian Sastra. Yogyakarta: Pustaka pelajar. 